Article

\title{
Extraction of Essential Oil from River Tea Tree (Melaleuca bracteata F. Muell.): Antioxidant and Antimicrobial Properties
}

\author{
Mursleen Yasin ${ }^{1, *}$, Adnan Younis ${ }^{1}$, Fahad Ramzan ${ }^{1}$, Talha Javed ${ }^{2,3}{ }^{\circledR}$, Rubab Shabbir ${ }^{2}{ }^{\infty}$,

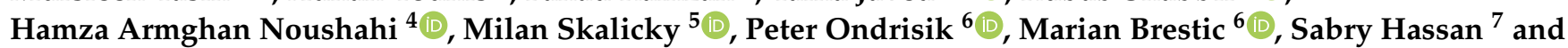 \\ Ayman EL Sabagh $8, *$ (i)
}

Citation: Yasin, M.; Younis, A.; Ramzan, F.; Javed, T.; Shabbir, R.; Noushahi, H.A.; Skalicky, M.; Ondrisik, P.; Brestic, M.; Hassan, S.; et al. Extraction of Essential Oil from River Tea Tree (Melaleuca bracteata $\mathrm{F}$. Muell.): Antioxidant and Antimicrobial Properties. Sustainability 2021, 13, 4827. https:// doi.org/10.3390/su13094827

Academic Editors: António Raposo and Marc A. Rosen

Received: 18 March 2021

Accepted: 22 April 2021

Published: 25 April 2021

Publisher's Note: MDPI stays neutral with regard to jurisdictional claims in published maps and institutional affiliations.

Copyright: (c) 2021 by the authors. Licensee MDPI, Basel, Switzerland. This article is an open access article distributed under the terms and conditions of the Creative Commons Attribution (CC BY) license (https:// creativecommons.org/licenses/by/ $4.0 /)$
1 Institute of Horticultural Sciences, University of Agriculture Faisalabad, Faisalabad 38040, Pakistan; adnanyounis@uaf.edu.pk (A.Y.); fahidflorist@yahoo.com (F.R.)

2 College of Agriculture, Fujian Agriculture and Forestry University, Fuzhou 350002, China; mtahaj@fafu.edu.cn (T.J.); rubabshabbir28@gmail.com (R.S.)

3 Department of Agronomy, University of Agriculture Faisalabad, Faisalabad 38040, Pakistan

4 College of Plant Science and Technology, Huazhong Agricultural University, Wuhan 430070, China; hamzanaushahi143@gmail.com

5 Department of Botany and Plant Physiology, Faculty of Agrobiology, Food and Natural Resources, Czech University of Life Sciences Prague, 16500 Prague, Czech Republic; skalicky@af.czu.cz

6 Department of Plant Physiology, Slovak University of Agriculture, 94901 Nitra, Slovakia; peter.ondrisik@uniag.sk (P.O.); marian.brestic@uniag.sk (M.B.)

7 Department of Biology, College of Science, Taif University, P.O. Box 11099, Taif 21944, Saudi Arabia; sabryh@lycos.com

8 Department of Agronomy, Faculty of Agriculture, University of Kafrelsheikh, Kafrelsheikh 33516, Egypt

* Correspondence: mursleenyasin@gmail.com (M.Y.); ayman.elsabagh@agr.kfs.edu.eg (A.E.S.)

Abstract: Tea tree oil (TTO) from the genus Melaleuca L. has antimicrobial, antibacterial, antifungal, and antioxidant properties and is used by the cosmetic, pharmaceutical, and horticultural industries In Pakistan, Melaleuca bracteata can be exploited for essential oil purposes, as this species is well adapted to Pakistan's agroclimatic conditions. The objective of the present study was to evaluate the yield of $M$. bracteata essential oil together with its antioxidant and antimicrobial properties under local prevailing conditions of the subtropics. Essential oil was extracted through the hydrodistillation method. Using this method, six batches of $8 \mathrm{~kg}$ samples (fresh leaves and branches) underwent a distillation process for $4-5 \mathrm{~h}$. The average yield obtained was about $0.2 \%$. The GCMS was used to identify the components of extracted essential oil. Eugenol methyl ether is the major component in extracted essential oil, i.e., $96 \%$ of the total. A high content of flavonoids and phenolics and a Fe-reducing power ability of $M$. bracteat $a$ were observed. The oil was also found effective against $B$. subtilis, B. cereus, White rot, and A. flavus. Hence, it is concluded that there is a possibility to use TTO for its biocidal properties, and it must also be inspected and then commercialized in Pakistan by the agriculture and cosmetic industries.

Keywords: Melaleuca bracteata; essential oil; hydrodistillation; eugenol methyl ether; antioxidant; antimicrobial

\section{Introduction}

Natural products from plants are under immense consideration in the organic world. One such utilization is of essential oils that are complex volatile compounds extracted from leaves, twigs, flowers, seeds, branches, buds, fruits, and roots. These secondary compounds are then stored in secretory cells, glandular trichomes, canals, cavities, and epidermal cells [1]. Use of essential oils (EOs) is expeditiously increased because of their antibacterial, antiviral, antifungal, insecticidal [1], anti-inflammatory [2], and antimicrobial traits [3]. EOs also have antidepressant and anxiolytic activities [4]. These characters are possessed by certain chemical compounds, mainly phenolics, alkaloids, flavonoids, glycosides, and flavonoids [5]. 
The Myrtaceae family would rank among the most important families of plants which are enriched with essential oils. Genus Melaleuca is one of the prominent members of the family Myrtaceae that is also well known for its essential oils. Melaleuca is indigenous to Australia yet can adjust into several agroclimatic conditions. The volatile oil product of this genus is familiar to the world with the name of tea tree oil (TTO). The species that are under commercial use for essential oil production are Melaleuca alternifolia, $M$. cajuputi, M. bracteata, and M. quinquenervia [6]. Plant extract including oil was used by Aboriginals and was also utilized by soldiers as a general antimicrobial and insect repellent in World War II [7]. Today, TTO is gaining popularity in different industries and being used in aromatherapy, herbal and allopathic medicines, cosmetics, and as natural biocide, fungicide, and preservative. The oil is slightly yellow colored to transparent with a strong camphor-like odor and menthol-like cooling effect $[8,9]$. The composition of TTO has almost 100 different chemicals, predominantly monoterpenes (terpinen-4-ol, terpinolene, p-cymene, $\alpha$-pinene, $\gamma$-terpinene, 1,8-cineole), sesquiterpenes, and their respective alcohols (monoterpene, alcohol-terpineol) [10].

In Pakistan, the Melaleuca genus has been cultivated in the Punjab region for a long time, but its properties and products are yet not investigated here. Melaleuca bracteata is one of the species that is well adapted to the agroclimatic conditions of Pakistan [11]. Tea tree oil contains antioxidant, cytotoxic, antifungal, insecticidal, and medicinal properties [12-14]. Reports have shown methyl eugenol and phenylpropanoids to be the prime components of tea tree oil from M. bracteata. Moreover, it can be inferred from literature that TTO can be used effectively by the horticulture sector as a chemical-free fungicide, bactericide, and for enhancement of the shelf life and vase life of fruits, vegetables, and flowers. Hence, it is necessary to test the effectiveness and appropriate use of this essential oil so it can be extracted and employed by the local industry more cost-effectively. Therefore, this study aims to investigate the local adapted species of tea tree oil for more exploration and assessment of this essential oil.

\section{Materials and Methods}

\subsection{Plant Material}

Fresh plant material including leaves and twigs were collected from the University of Agriculture Faisalabad and Qadir Baksh Nursery Farms Faisalabad, Pakistan $\left(31.43^{\circ} \mathrm{N}\right.$, $73.07^{\circ} \mathrm{E}$ ). The sample for extraction was prepared by clipping leaves and young twigs into smaller pieces.

\subsection{Extraction Method}

Essential oil was extracted from Melaleuca via the hydrodistillation technique at the Department of Chemistry, University of Agriculture Faisalabad, Pakistan $\left(31.43^{\circ} \mathrm{N}\right.$, $\left.73.07^{\circ} \mathrm{E}\right)$. The unit consisted of a distillation flask/tank, condenser, and thermometer. About $8-10 \mathrm{~kg}$ of plant material was added in flask and submerged into $12 \mathrm{~L}$ of water. Then, the set up was airtightly closed, and the process was started at $250{ }^{\circ} \mathrm{C}$ temperature. The procedure continued for 4-5 h. Oil was collected in a separating funnel. The \%age yield of the extracted oil $(v / w)$ was calculated by the following formula [15], and then the oil was stored at a cool dry place [16].

Essential Oil Yield \% = Volume of extracted oil/Fresh weight of plant material $(\mathrm{g}) \times 100$.

\subsection{Analysis of Tea Tree oil by GCMS}

The extracted oil samples were subjected to compound analysis via the gas chromatography-mass spectrometer technique. The detector of Agilent 5975C was used, and it was provisioned with 7890A GC and column of HP-5MS with $30 \mathrm{~m}$ length, 250 micrometer width, and 0.25 micrometer internal diameter with a temperature of $450^{\circ} \mathrm{C}$. The oven program was kept on, and the equilibrium time for the oven was $0 \mathrm{~min}$. The program was run for $36 \mathrm{~min}$, and the temperature of the heater was $240{ }^{\circ} \mathrm{C}$. The inert gas 
used as a carrier was Helium with a flow rate of $0.7 \mathrm{~mL} / \mathrm{min}$. Mass spectrometry was performed in EMV mode at relative voltage of $59 \mathrm{eV}$ and scan range from 50 to $550 \mathrm{amu}$. The mass spectrometer was equipped with a gold standard quadrupole analyzer at $150{ }^{\circ} \mathrm{C}$ $\left(\max 200^{\circ} \mathrm{C}\right)$. The temperature of MS source was $240^{\circ} \mathrm{C}\left(\max 250^{\circ} \mathrm{C}\right)$. The Agilent MSD Productivity ChemStation 6 was the software which identified the compounds receiving signals at the same time from both detectors [15].

\subsection{Antioxidant Analysis}

\subsubsection{DPPH Radical Scavenging Activity}

Radical scavenging activity is the ability of an antioxidant compound to protect cells from free radicals produced during normal cell metabolism. To check this character of tea tree oil, DPPH (2,2-diphenyl-1-picrylhydrazyl) scavenging activity was carried out. For this purpose, $1.0 \mathrm{~mL}$ at $0.3 \mathrm{M}$ of 1,1-diphenyl-2-picrylhydrazyl was added to the $2.5 \mathrm{~mL}$ solution of the sample and gallic acid standard. Standards of gallic acid were prepared at 20,40,60, 80 , and $100 \mathrm{ppm}$. Then, all the test tubes were incubated at room temperature for $20 \mathrm{~min}$ and kept in the dark. After that, absorbance was recorded at $518 \mathrm{~nm}$ by spectrophotometer (T60 U Spectrophotometer, PG Instruments Ltd., Leicestershire, UK). DPPH 100 ppm was used as control treatment, and absorbance was recorded as Abs control. A blank experiment of $80 \%$ ethanol was run as well, and absorbance was calculated as Abs blank. The DPPH scavenging activity was determined from the following expression [17].

DPPH scavenging activity $(\%)=100-\{[($ Abs sample-Abs blank $) \times 100] /$ Abs control $]\}$

\subsubsection{Total Flavonoid Contents}

Flavonoid compounds are antioxidants present in plants and all fruits and vegetables. To evaluate this in tea tree oil, $1.0 \mathrm{~mL}$ of samples and catechin standards at 20,40,60, 80, and 100 ppm were added in $4.0 \mathrm{~mL}$ of distilled water. The solution was prepared in a volumetric flask of $10 \mathrm{~mL}$ capacity. After this, $5 \% \mathrm{NaNO}_{2}$ weighing $0.3 \mathrm{~mL}$ was mixed in the above prepared solution. $1 \mathrm{M} \mathrm{NaOH}(2 \mathrm{~mL})$ was added after $1 \mathrm{~min}$, and later, after $5 \mathrm{~m}$, $0.3 \mathrm{~mL}$ of $10 \% \mathrm{AlCl}_{3}$ was also mixed. After $60 \mathrm{~s}, 2 \mathrm{~mL}$ of $1 \mathrm{M} \mathrm{NaOH}$ was added to make the total volume up to $10 \mathrm{~mL}$ by deionized distilled water. We mixed it thoroughly, and absorbance was observed at $510 \mathrm{~nm}$ using reagent blank. Catechin equivalent in milligram per gram dry plant material was used to present the total flavonoids in TTO [18].

\subsubsection{Total Phenolic Compounds}

To estimate the phenolic compounds of tea tree oil, gallic acid standards at 20,40,60, 80, and $100 \mathrm{ppm}$ were used. To $1.0 \mathrm{~mL}$ volume of both samples and standards, $5.0 \mathrm{~mL}$ of FolinCiocalteu (Fisher chemicals) and $4 \mathrm{~mL}$ of $\mathrm{Na}_{2} \mathrm{CO}_{3}(7 \% \mathrm{w} / \mathrm{v})$ were added with continuous shaking. Then, all the solutions were kept in dark for $30 \mathrm{~min}$, and later on, absorbance was detected at $765 \mathrm{~nm}$ with the help of a spectrophotometer (T60 U Spectrophotometer, PG Instruments Ltd., Leicestershire, UK). A blank sample used was a reagent solution. A gallic acid equivalent (GAE) was used to express the amount of total phenolics based on milligram per gram of plant dry weight [19].

\subsubsection{Reducing Power Ability (RPA) of the Plant}

It is determined by adding $1.0 \mathrm{~mL}$ gallic acid standard solutions and sample to 0.2 molar solution of phosphate buffer solution $(2.3 \mathrm{~mL})$ at $6.6 \mathrm{pH}$. Then, $2.5 \mathrm{~mL}$ of $1 \%$ potassium ferricyanide $\left(\mathrm{K}_{3}\left[\mathrm{Fe}(\mathrm{CN})_{6}\right]\right)$ was added to the solution. Incubation of the mixture was done at $37^{\circ} \mathrm{C}$ for $20 \mathrm{~m}$. Then, $10 \%$ trichloroacetic acid $(2.5 \mathrm{~mL})$ was mixed and then centrifuged at $1000 \mathrm{rpm}$ for $10 \mathrm{~m}$. The supernatant with a $2.5 \mathrm{~mL}$ volume was mixed with distilled water and $0.5 \mathrm{~mL}$ of $0.1 \% \mathrm{FeCl}_{3}$. After $10 \mathrm{~m}$, absorbance was determined at $700 \mathrm{~nm}$ using a spectrophotometer (T60 U Spectrophotometer, PG Instruments Ltd., Leicestershire, UK) [20]. 


\subsection{Antimicrobial Analysis}

The inhibitory zone (IZ) assay of tea tree oil was tested on microbes using the disc diffusion method as proposed by Al-Abd et al. [21]. Firstly, an agar plate was prepared by spreading the microbe, then paper disks of antimicrobials were added. This method is mostly used to determine the best antibiotic against a new or drug-resistant pathogen. The zone of inhibitions was measured with the help of a transparent scale in millimeters [22]. The bacterial strains tested by this procedure were Bacillus subtilis and Bacillus cereus. The fungal strains evaluated against tea tree oil were White rot and Aspergillus flavus.

\subsection{Statistical Analysis}

The lab experiments were conducted through a completely randomized design (CRD). Data were analyzed using Statistix 8.1 software (https: / / www.statistix.com/ (accessed on: 9 February 2020)), and mean analysis was conducted through Tukey's honestly significant difference test on a 0.05 level of probability [23].

\section{Results and Discussion}

\subsection{Essential Oil Yield}

Yield of essential oil via the hydrodistillation method was about $0.2 \%$, as shown in Table 1 . The volume of extracted oil could vary based on the agroclimatic and geographical conditions of the area. A study by Siddique et al. [24] reported the \%age yield of Melaleuca bracteata to range at $0.14 \pm 0.01 \%$ in Pakistan. The percentage yield of extracted oil of each hydrodistillation batch is shown in Table 1 .

Table 1. \%age Yield of tea tree oil from M. bracteata leaves.

\begin{tabular}{cc}
\hline Batch No. & \% Age Yield \\
\hline 1 & $0.25 \pm 0.017$ \\
2 & $0.2 \pm 0.017$ \\
3 & $0.15 \pm 0.015$ \\
\hline
\end{tabular}

\subsection{GCMS Analysis}

The GCMS analysis of tea tree oil from $M$. bracteata showed the 7 peaks as shown in Figure 1. Table 2 indicates that methyl eugenol is the supreme compound of tea tree oil extracted from Melaleuca bracteata species. It represents $96 \%$ of the total, and the other six contents were found as just trace elements. The other elements in order of percentage are p-Mentha-2,8-diene-1-ol, Methyl cinnamate, Germacrene D, Terpinolene, Linalool, and alpha-phellandrene. Previous literature has also proclaimed methyl eugenol as the major component of $M$. bracteata oil, with $86.5 \%$ of the total volume [24,25]. The latter also indicated methyl cinnamate as the second highest compound, representing $11 \%$ of the total. However, another team of scientists documented the percentage of methyl eugenol to be greater than $95 \%$ in the tea tree oil of bracteata, which is quite related to the present finding [26].

Table 2. GC-MS analysis of tea tree oil from Melaleuca bracteata.

\begin{tabular}{cccc}
\hline Peak No. & Identified Compounds & $\begin{array}{c}\text { Retention Time } \\
(\mathbf{m i n})\end{array}$ & $\begin{array}{c}\text { \% of } \\
\text { Total }\end{array}$ \\
\hline $\mathbf{1}$ & alpha-phellendrene & 8.568 & $0.49 \%$ \\
$\mathbf{2}$ & p-Mentha-2,8-diene-1-ol & 9.278 & $0.92 \%$ \\
$\mathbf{3}$ & Terpinolene & 11.071 & $0.64 \%$ \\
$\mathbf{4}$ & Linalool & 11.595 & $0.50 \%$ \\
$\mathbf{5}$ & Methyl cinnamate & 19.359 & $0.77 \%$ \\
$\mathbf{6}$ & Methyl eugenol & 19.897 & $96.02 \%$ \\
$\mathbf{7}$ & Germacrene D & 20.663 & $0.67 \%$ \\
\hline
\end{tabular}




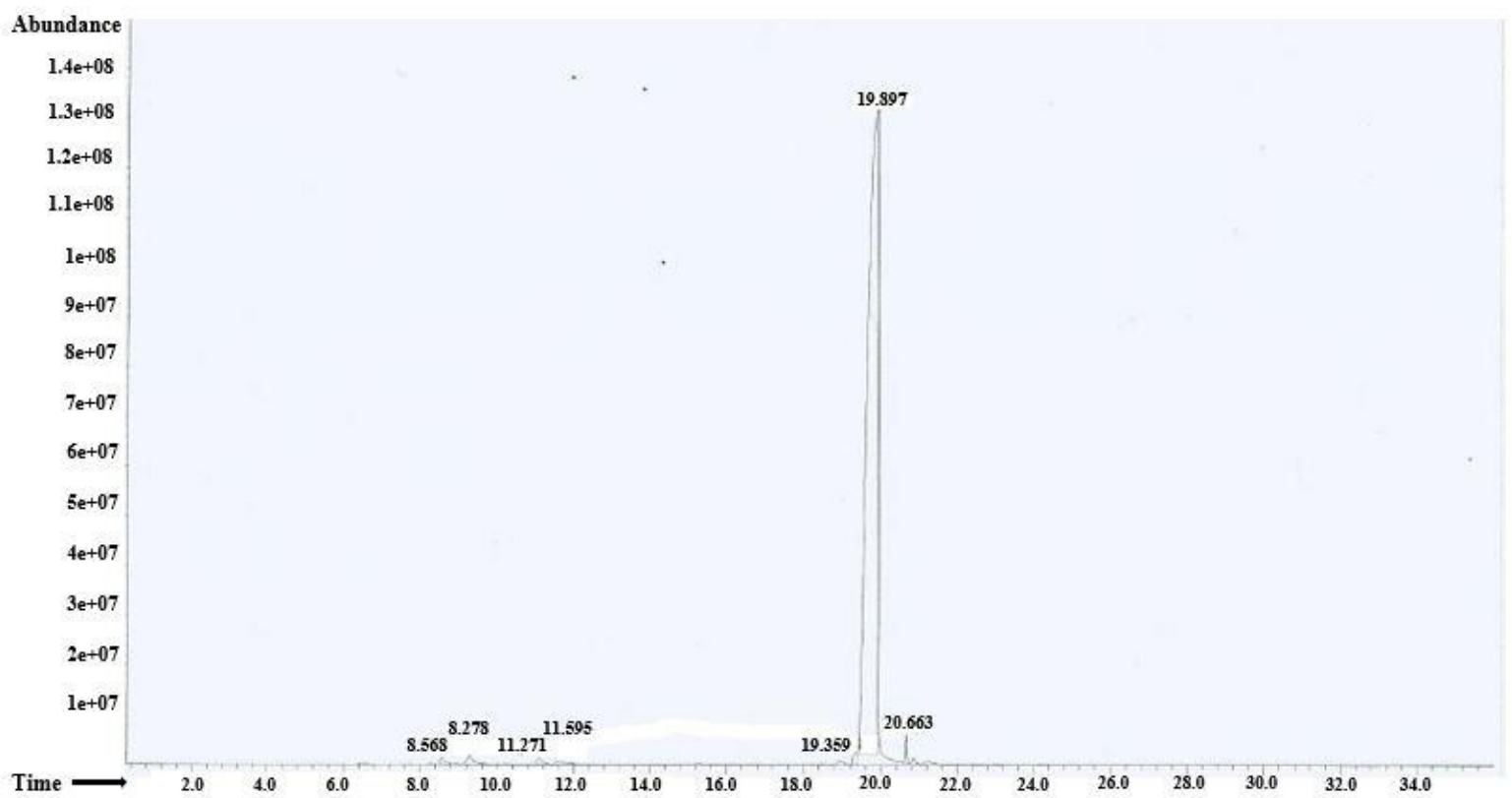

Figure 1. Chromatogram of TTO by GCMS analysis.

Methyl eugenol (ME) belongs to phenylpropanoids, and its occurrence is found in 450 species of plants. In nature, ME is known for plant chemical defense as an antifungal, antibacterial, antinematode and has toxic activities against insect pathogens [27]. The oil from Echinophora sibthorpiana (Apiaceae) also has methyl eugenol. Kivanc [28] found that its oil $(\sim 0.1 \%)$ and $\mathrm{ME}$ at $0.05-0.1 \%$ have negative effects on the growth of fungi and bacteria. Later, Kivanc and Akgul [29] identified that eugenol methyl ether at 1000 ppm also detained mycelium and spore formation of Aspergillus and Penicillium strains. It has also been found to inhibit fungal infestation in peanuts by Sudhakar et al. [30]. ME has been shown to act as a floral synomone in the coevolution of orchid species in the genus Bulbophyllum with fruit flies. It was recognized as the best insect repellent and most effective in knockdown and killing effects among the major constituents of EOs [31]. The importance of methyl eugenol can also be inferred from the findings of Rossi et al. [32] that volatile oil from carrot was successfully evaluated to inhibit the growth of Campylobacter jejuni, a major gastroenteritis-causing bacterium across the globe. Methyl eugenol, a component of carrot oil, was also found effective separately at a minimum inhibitory concentration of $250 \mu \mathrm{g} / \mathrm{mL}$.

\subsection{Biochemical Assays}

The oil extracted from Melaleuca species exhibited competent antioxidant properties. The result is supported by Table 3, which shows the antioxidant values of M. bracteata oil along with the mean and standard error values.

Table 3. Average antioxidant values of TTO from Melaleuca bracteata.

\begin{tabular}{ccccc}
\hline Replication No. & $\begin{array}{c}\text { TFC Value } \\
\text { (mm/g) }\end{array}$ & $\begin{array}{c}\text { TPC Value } \\
(\mathbf{m m} / \mathbf{g})\end{array}$ & $\begin{array}{c}\text { RPA Value } \\
\text { (mm/g) }\end{array}$ & $\begin{array}{c}\text { DPPH } \\
\text { \%Age }\end{array}$ \\
\hline R1 & 955.67 & 108.945 & 300.79 & 89.13 \\
R2 & 942.16 & 108.945 & 314.88 & 86.95 \\
R3 & 955.67 & 112.145 & 307.81 & 84.45 \\
Mean & 951.16 & 110.01 & 307.83 & 86.84 \\
S.D & 7.80 & 1.84 & 7.04 & 4.22 \\
S.E & 4.50 & 2.60 & 4.06 & 2.43 \\
\hline
\end{tabular}

TFC: total flavonoid contents, TPC: total phenolic compounds, RPA: reducing power ability, DPPH: 2,2-diphenyl1-picrylhydrazyl. 


\subsubsection{DPPH Scavenging Activity}

In Table 3, the average scavenging activity of tea tree oil is displayed. DPPH values for $M$. bracteata oil ranged at $86.848 \pm 2.43 \mathrm{mg} / \mathrm{mL}$ from the three replicates.

\subsubsection{Total Flavonoid Contents}

From Table 3, it is inferred that TTO has a relatively higher amount of flavonoids, i.e., $951 \pm 4.50 \mathrm{mg} / \mathrm{mL}$. Flavonoids are produced in plants as a response to oxidative pressure and photodamage via secondary metabolic processes $[33,34]$.

\subsubsection{Total Phenolic Compounds of Tea Tree Oil}

The TPC of tea tree oil were exploited with respect to the gallic acid standard. The slope expression obtained from the standard curve was used to calculate the concentration of phenolics as a gallic acid equivalent (GAE) in $\mathrm{mg} / \mathrm{g}$ of plant dry weight basis. Table 3 represents a higher concentration of phenolics, i.e., $110 \mathrm{mg} / \mathrm{g}$ of the dry weight of Melaleuca bracteata plant.

\subsubsection{Reducing Power Ability}

Antioxidants reduce $\mathrm{Fe}^{3+}$ to $\mathrm{Fe}^{2}$, i.e., ferricyanide complex to the ferrous form. This transformation is observed at $700 \mathrm{~nm}$ [35]. The reducing ability is amplified with increased absorbance [36]. RPA values were evaluated as equivalent to the standard. About $308 \mathrm{mg} / \mathrm{g}$ of the dry weight of the plant was found in Melaleuca bracteata oil. A study by Hou et al. [37] provided evidence regarding the antioxidant potential of Melaleuca bracteata. When extraction was done with conventional methods, the total phenolic compounds found were $88.6 \pm 1.3 \mathrm{mg}$, and the total flavonoids were $19.4 \pm 0.2 \mathrm{mg}$. The DPPH scavenging activity was high at $86 \pm 0.3 \%$. After conditions were optimized, all the values of antioxidants were heightened and found to be at their peak values of $98.7 \pm 1.2 \mathrm{mg}$, $21.6 \pm 0.3 \mathrm{mg}$, and $94.7 \pm 0.8 \%$ for TPC, TFC, and DPPH, respectively. Siddique et al. [24] also reported that scavenging activity in M. bracteata ranged between 35.3 and $89.2 \pm 0.4 \%$. This potential increased with the increase of concentration of oil from 20 to $100 \mu \mathrm{g} / \mathrm{mL}$.

Tea tree oil is an effective antioxidant agent as its commercial species, i.e., Melaleuca alternifolia, has also been observed to be enriched with this potential by several reports. One such is the study of Noumi et al. [38] in which DPPH scavenging activity was recorded at $12.5 \mu \mathrm{g} / \mathrm{mL}$ expressed as IC50 values (the concentration of antioxidant at which $50 \%$ of the reaction was inhibited). The power of TTO as an antioxidant was also found to be better than that of common synthetic antioxidant butylated hydroxytoluene (BHT) at $30 \mathrm{mM}$. Previous researchers proposed TTO as a good alternative to maintain the oxidative stability of the food matrix. Additionally, when compared with other natural oxidants such as vitamin C, vitamin E, and quercetin, Melaleuca alternifolia oil expressed strong free radical scavenging properties and inhibited lipid peroxidation [39]. This is because of the presence of phenols in this oil, which reduce the aerobic oxidation of organic matter [40]. Hence, it is concluded that the present detection of antioxidants in tea tree oil from Melaleuca bracteata is in accordance with previous reports of several scientific studies, and this species could also be explored as an antioxidative essential oil along with its patent plant species (Melaleuca alternifolia).

\subsection{Antimicrobial Properties}

Bacillus subtilis and Bacillus cereus were tested against tea tree oil from Melaleuca bracteata. The zone of inhibition was measured in millimeters for all treatments. It is the measure of a clear region with no microbial growth around the paper disc on the agar surface. The clear area represents the resistance or the effective inhibition of microbial growth by antimicrobial agent. The larger the region is, the greater the antimicrobial effect of the agent. the effect of tea tree oil on the growth of Bacillus subtilis and Bacillus cereus is elaborated on in Figure 2. The zone of inhibition obtained by the application of M. bracteata 
oil was 19.5 and $13 \mathrm{~mm} \pm 0.43$. The oil was efficient in controlling bacterial growth better than standard treatment.

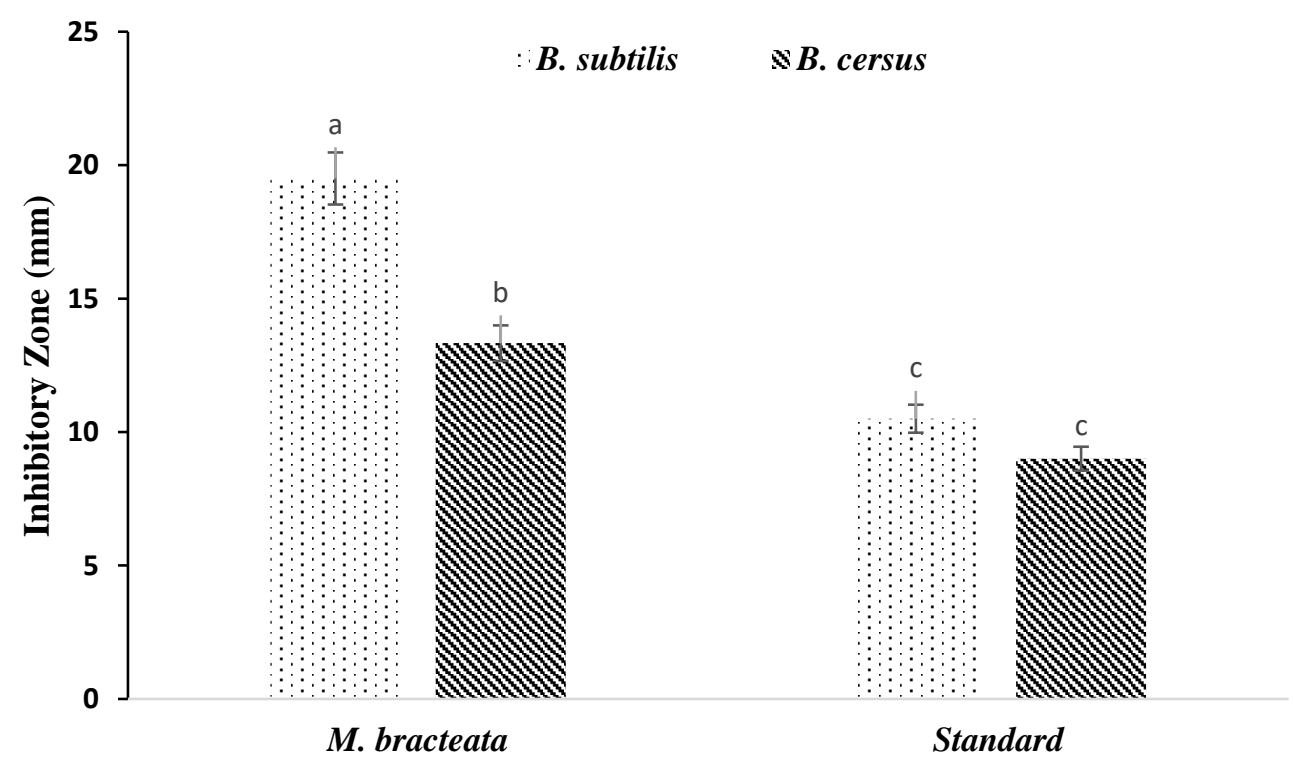

Figure 2. Zone of inhibition calculated from M. bracteata oil sample and standard against Bacillus species.

Melaleuca species possess good antibacterial effects against Bacillus strains. Previously, in a finding by Goswami et al. [41], the zone of inhibition for B. subtilis by M. bracteata oil was measured to be 6-7 $\mathrm{mm}$, which showed a moderate antifungal effect of essential oil on the bacterial strain. The growth of B. subtilis subsp. Spizizenii was also inhibited by this oil species at $250 \mu \mathrm{g} / \mathrm{mL}$ up to $44 \mathrm{~mm}$ zone of inhibition [24]. EO from this species was also found to be effective against Staphylococcus aureus strains, S. epidermidis, Klebsiella pneumonia, and Streptococcus mutans when tested by Goswami et al. (2017) [41]. The MIC of M. alternifolia oil counted for Bacillus cereus was $0.3 \%(v / v)$ by Griffin et al. [42]. Previous literature reported that TTO has a bactericidal activity against Staphylococcus species, Lactobacillus, Actinomyces viscosus, and E. coli [43-46]. The antimicrobial traits of $M$. alternifolia have been employed to its terpinen-4-ol compound [47,48]. Moreover, terpinen-4-ol and methyl eugenol from both the species have been recognized to have efficient antibacterial, antifungal, and antinematode properties [14,27].

\subsection{Antifungal Properties}

The potential of fungicidal effects of tea tree oil was evaluated by measuring its zone of inhibition for Aspergillus flavus and Phanerochaete chrysosporium (White rot). From Figure 3, it is inferred that the growth of White rot fungi and A. flavus was restricted up to $11.67 \mathrm{~mm}$ and $10.5 \mathrm{~mm}$ by the application of oil from M. bracteata species, respectively.

Shin [49] has documented the antifungal aspects of commercial TTO from M. alternifolia against Aspergillus flavus. The concentration required for the effective control on fungus ranged between 0.3 and 0.7 (\% volume by volume). The oil has been found to be effective against other Aspergillus species such as A. niger with a minimum inhibitory concentration of 0.016 to 0.4 (\%volume/volume). The effective antifungal agent is terpinen-4-ol in this oil. Moreover, the zone of inhibition formed by methyl eugenol from the oil of another Melaleuca species was $24.3 \pm 0.3 \mathrm{~mm}$ for pure oil and $46 \pm 0.6 \mathrm{~mm}$ at $100 \mu \mathrm{g} / \mathrm{mL}$ of oil against Fusarium oxysporum [50]. Homeyer et al. [51] observed that within $15 \mathrm{~min}$ of exposure, TTO reduced the $\log$ of Fusarium oxysporum up to -4 as compared to control treatment. 


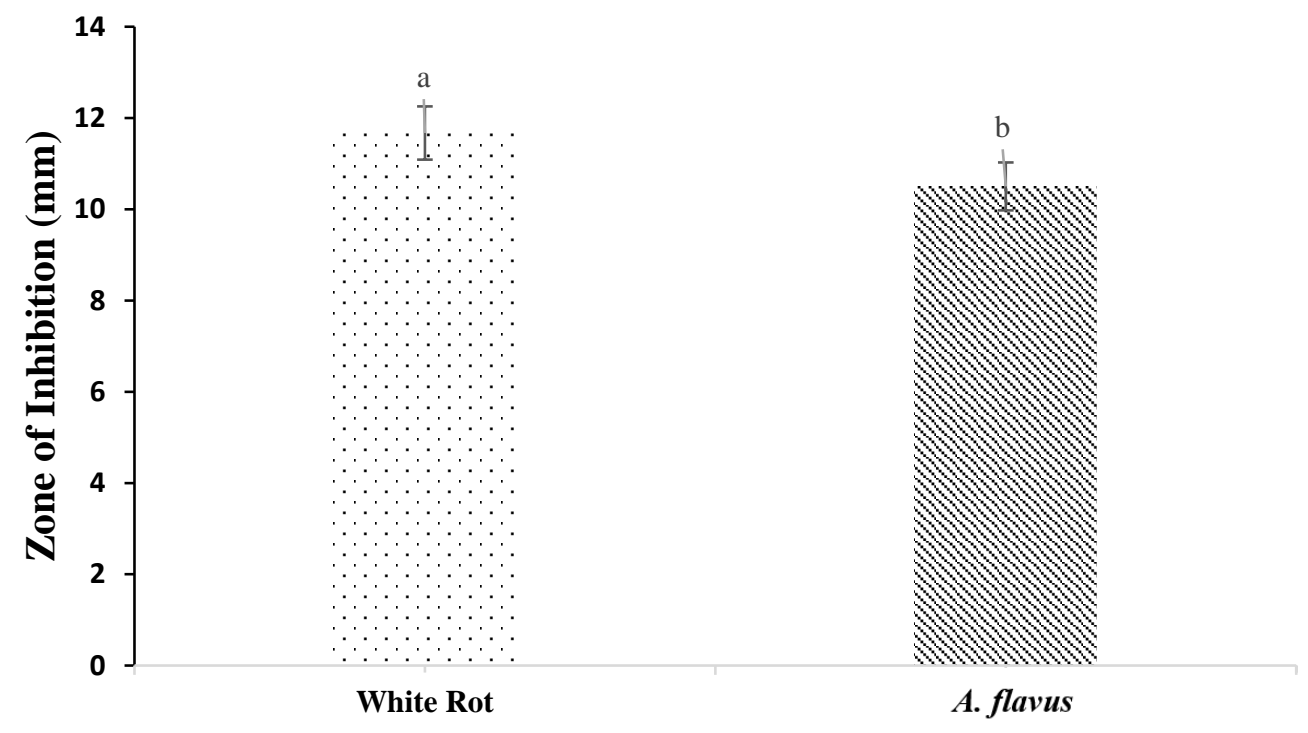

Figure 3. Zone of inhibition calculated from M. bracteata oil against White Rot and Aspergillus flavus.

\section{Conclusions}

The present study aimed at the extraction of essential oil from Melaleuca bracteata to explore its antioxidant and antimicrobial properties. It has been found from the results that the yield percentage for essential oil is about $2 \%$ through the hydrodistillation method, and it is enriched with eugenol methyl ether. A high antioxidant activity is observed when measured on scales for total flavonoids, total phenolics, reducing power ability, and DPPH. The laboratory application of TTO on microbes reduces their activity. Thus, tea tree oil from Melaleuca bracteata species has significant potential as an antioxidant and antimicrobial to be used as a natural microbicide in the food and agriculture industries. The Bracteata species is well adapted to Pakistan and specifically the Punjab region's climate. Thus, it must be exploited by the local industry to produce raw and refined oil products to commercialize its use in horticulture, pharmaceuticals, and cosmetics.

Author Contributions: Conceptualization, A.Y.; methodology, M.Y.; software, M.Y.; validation, T.J., R.S., F.R. and A.E.S.; formal analysis, M.Y.; investigation, M.Y.; resources, A.Y.; data curation, T.J., R.S. and A.E.S.; writing—original draft preparation, M.Y.; writing—review and editing, M.S., M.B., P.O., A.Y., T.J., H.A.N. and A.E.S.; supervision, A.Y.; project administration, A.Y.; funding acquisition, S.H., A.Y. and A.E.S. All authors have read and agreed to the published version of the manuscript.

Funding: The authors was funded by Taif University Researchers Supporting Project grant number (TURSP-2020/142), Saudi Arabia.

Acknowledgments: The authors are highly grateful to Taif University Researchers Supporting Project Number (TURSP-2020/142), Saudi Arabia. The authors thank Muhammad Zaryab Khalid for critically reviewing the manuscript.

Conflicts of Interest: The authors declare no conflict of interest.

\section{References}

1. Bakkali, F.; Averbeck, S.; Averbeck, D.; Idaomar, M. Biological effects of essential oils-A review. Food Chem. Toxicol. 2008, 46, 446-475. [CrossRef] [PubMed]

2. Andrade, L.; de Sousa, D. A review on anti-inflammatory activity of monoterpenes. Molecules 2013, 18, 1227-1254.

3. Andrade, B.F.M.T.; Barbosa, L.N.; Probst, I.D.S.; Júnior, A.F. Antimicrobial activity of essential oils. J. Essent. Oil Res. 2014, 26, 34-40. [CrossRef]

4. De Almeida, R.N.; Motta, S.C.; Faturi, C.D.B.; Catallani, B.; Leite, J.R. Anxiolytic-like effects of rose oil inhalation on the elevated plus-maze test in rats. Pharmacol. Biochem. Behav. 2004, 77, 361-364. [CrossRef] 
5. Solgi, M.; Kafi, M.; Taghavi, T.T.; Naderi, R. Effects of Silver Nanoparticles and Essential Oils of Thyme (Thymus vulgaris) and Zattar (Zataria multiflora Boiss.) on Postharvest Qualitative Aspects of Gerbera Cut Flowers (Gerbera jamesonii L.). Ph.D Thesis, Tehran University, Tehran, Iran, 2009.

6. Padalia, R.C.; Verma, R.S.; Chauhan, A.; Goswami, P.; Verma, S.K.; Darokar, M.P. Essential oil of Melaleuca linariifolia Sm. from India: A potential source of 1,8-cineole. Ind. Crops Prod. 2015, 63, 264-268. [CrossRef]

7. Lis-Balchin, M.; Deans, S.G. Bioactivity of selected plant essential oils against Listeria monocytogenes. J. Appl. Microbiol. 1997, 82, 759-762. [CrossRef]

8. Larson, D.; Jacob, S.E. Tea tree oil. Dermatitis 2012, 23, 48-49. [CrossRef]

9. Hammer, K.A. Treatment of acne with tea tree oil (Melaleuca) products: A review of efficacy, tolerability and potential modes of action. Int. J. Antimicrob. Agents 2015, 45, 106-110. [CrossRef]

10. Nogueira, M.N.M.; Aquino, S.G.; Rossa Junior, C.; Spolidorio, D.M.P. Terpinen-4-ol and alpha-terpineol (tea tree oil components) inhibit the production of IL-1b, IL-6 and IL-10 on human macrophages. Inflamm. Res. 2014, 63, 769-778. [CrossRef]

11. Parker, R.N.A. Forest Flora for the Punjab with Hazara and Delhi, Superintendent; Government of Printing Press: Panaji, India, 1956; pp. 245-246.

12. Yatagai, M. Allelopathy, control of plant ecosystem by plant chemical components: Chemical characteristics and activity of plant odor components. Aroma. Res. 2007, 8, 408-413.

13. Adesanwo, J.K.; Shode, F.O.; Aiyelaagbe, O.O.; Rabiu, O.O.; Oyede, R.T.; Oluwole, F.S. Antisecretory and antiulcerogenic activities of the stem bark extract of Melaleuca bracteata and isolation of principles. J. Med. Plants Res. 2009, 3, 822-824.

14. Kardinan, A.K.; Hidayat, P. Potency of Melaleuca bracteata and Ocimum sp. leaf extracts as fruit fly (Bactrocera dorsalis complex) attractants in guava and star fruit orchards in Bogor, West Java, Indonesia. J. Sustain. Agric. 2013, 8, 79-84.

15. Bistgani, Z.E.; Siadat, S.A.; Bakhshandeh, A.; Pirbalouti, A.G.; Hashemi, M.; Maggi, F.; Morshedloo, M.R. Application of combined fertilizers improves biomass, essential oil yield, aroma profile, and antioxidant properties of Thymus daenensis Celak. Ind. Crops Prod. 2018, 121, 434-440. [CrossRef]

16. Berka-Zougali, B.; Ferhat, M.A.; Hassani, A.; Chemat, F.; Allaf, K.S. Comparative study of essential oils extracted from Algerian Myrtus communis L. leaves using microwaves and hydrodistillation. Int. J. Mol. Sci. 2012, 13, 4673-4695. [CrossRef]

17. Mensor, L.I.; Menezes, F.S.; Leitao, G.G.; Reis, A.S.; Santos, T.; Coube, C.S.; Leitao, S.G. Screening of Brazilian plant extracts for antioxidant activity by the use of DPPH Free Radical method. Phytother. Res. 2001, 15, 127-130. [CrossRef] [PubMed]

18. Zhishen, J.; Mengcheng, T.; Jianming, W. The determination of flavonoid contents in mulberry and their scavenging effects on superoxide radicals. Food Chem. 1999, 64, 555-559. [CrossRef]

19. Kujala, T.S.; Loponen, J.M.; Klika, K.D.; Pihlaja, K. Phenolics and betacyanins in red beetroot (Beta vulgaris) root: Distribution and effect of cold storage on the content of total phenolics and three individual Compounds. J. Agric. Food Chem. 2000, 48, 5338-5342. [CrossRef] [PubMed]

20. Habila, J.D.; Bello, I.A.; Dzikwi, A.A.; Musa, H.; Abubakar, N. Total phenolics and antioxidant activity of Tridax procumbens Linn. Afr. J. Pharm. Pharmacol. 2010, 4, 123-126.

21. Al-Abd, N.M.; Nor, Z.M.; Mansor, M.; Azhar, F.; Hasan, M.S.; Kassim, M. Antioxidant, antibacterial activity, and phytochemical characterization of Melaleuca cajuputi extract. BMC Complement. Alternat. Med. 2015, 15, 385. [CrossRef]

22. Kamal, S.; Kiran, S.; Aslam, N.; Bibi, I.; Rehman, J.; Manzoor, M.; Kamal, A. Mineral profile, antioxidant and antimicrobial activities of gemm Foeniculum vulgare. Curr. Biot. 2014, 8, 111-124.

23. Steel, R.G.; Torrie, J.H.; Dickey, D.A. Principles and Procedures of Statistics: A Biometrical Approach; McGraw-Hill Kogakusha Ltd.: Boston, MA, USA, 1997; Volume 2.

24. Siddique, S.; Parveen, Z.; Firdaus-e-Bareen; Mazhar, S. Chemical composition, antibacterial and antioxidant activities of essential oils from leaves of three Melaleuca species of Pakistani flora. Arab. J. Chem. 2020, 13, 67-74. [CrossRef]

25. Li, Y.; Ye, Z.; Wang, W.; Yang, C.; Liu, J.; Zhou, L.; Shen, Y.; Wang, Z.; Chen, J.; Wu, S.; et al. Composition analysis of essential oil from Melaleuca bracteata leaves using ultrasound-assisted extraction and its antioxidative and antimicrobial activities. BioResources 2018, 13, 8488-8504. [CrossRef]

26. Zhong, C.; Huang, Z.; Ling, Z.; Cheng, H. Study on chemical components of essential oil from the branches and leaves of Melaleuca bracteata. Flav. Frag. Cos. 2009, 6, 4.

27. Tan, K.H.; Nishida, R. Methyl eugenol: Its occurrence, distribution, and role in nature, especially in relation to insect behavior and pollination. J. Insect. Sci. 2012, 12, 1. [CrossRef]

28. Kivanc, M. Antimicrobial activity of "Cortuk" (Echinophora sibthorpiana Guss.) spice, its essential oil and methyl eugenol. Nahrung 1998, 332, 635-637. [CrossRef] [PubMed]

29. Kivanc, M.; Akgul, A. Mould growth on black table olives and prevention by sorbic acid, methyl-eugenol and spice essential oil. Nahrung 1990, 34, 369-373. [CrossRef]

30. Sudhakar, P.; Latha, P.; Sreenivasulu, Y.; Reddy, B.V.; Hemalaatha, T.M.; Balakrishna, M.; Reddy, K.R. Inhibition of Aspergillus flavus colonization and aflatoxin (AfB1) in peanut by methyl eugenol. Indian J. Exp. Biol. 2009, 47, $63-67$.

31. Ngoh, S.P.; Choo, L.E.W.; Pang, F.Y.; Huang, Y.; Kini, M.R.; Ho, S.H. Insecticidal and repellent properties of nine volatile constituents of essential oils against the American cockroach, Periplaneta americana (L.). Pestic. Sci. 1998, 54, 261-268. [CrossRef] 
32. Rossi, P.; Bao, L.; Luciani, A.; Panighi, J.; Desjobert, J.; Costa, J.; Casanova, J.; Bolla, J.; Berti, L. Methyl isoeugenol and elemicin: Antibaterial components of Daucus carota L. essential oil against Campylobacter jujuni. J. Agric. Food Chem. 2007, 55, 7332-7336. [CrossRef] [PubMed]

33. Close, D.C.; McArthur, C. Rethinking the role of many plant phenolics-protection from photodamage not herbivores? Oikos 2002, 9, 166-172. [CrossRef]

34. Treutter, D. Significance of flavonoids in plant resistance and enhancement of their biosynthesis. Plant Biol. 2005, 7, 581-591. [CrossRef]

35. Sousa, A.; Ferreira, I.C.F.R.; Barros, L.; Bento, A. Pereira Antioxidant potential of traditional stoned table olives "Alcaparras": Influence of the solvent and temperature extraction conditions. LWT Food Sci. Technol. 2008, 41, 739-745. [CrossRef]

36. Joshi, S.C.; Verma, A.R.; Mathela, C.S. Antioxidant and antibacterial activities of the leaf essential oils of Himalayan Lauraceae species. J. Chem. Toxicol. 2010, 48, 37-40. [CrossRef]

37. Hou, W.; Zhang, W.; Chen, G.; Lou, Y. Optimization of extraction conditions for maximal phenolic, flavonoid and antioxidant activity from Melaleuca bracteata leaves using the response surface methodology. PLoS ONE 2016, 11, e0162139. [CrossRef]

38. Noumi, E.; Snoussi, M.; Hajlaoui, H.; Trabelsi, N.; Ksouri, R.; Valentin, E.; Bakhrouf, A. Chemical composition, antioxidant and antifungal potential of Melaleuca alternifolia (tea tree) and Eucalyptus globulus essential oils against oral Candida species. J. Med. Plants Res. 2011, 5, 4147-4156.

39. Zhang, X.; Guo, Y.; Guo, L.; Jiang, H.; Ji, Q. In Vitro evaluation of antioxidant and antimicrobial activities of Melaleuca alternifolia essential oil. BioMed Res. Int. 2018, 3, 1-8. [CrossRef]

40. Amorati, R.; Foti, M.C.; Valgimigli, L. Antioxidant activity of essential oils. J. Agric. Food Chem. 2013, 61, 10835-10847. [CrossRef] [PubMed]

41. Goswami, P.; Verma, S.K.; Chauhan, A.; Venkatesha, K.T.; Verma, R.S.; Singh, R.V.; Darokar, M.P.; Chanotiya, C.S.; Padalia, R.C. Chemical composition and antibacterial activity of Melaleuca bracteata essential oil from India: A natural source of methyl eugenol. Nat. Prod. Commun. 2017, 12, 1934578X1701200633. [CrossRef]

42. Griffin, S.G.; Markham, J.L.; Leach, D.N. An agar dilution method for the determination of the minimum inhibitory concentration of essential oils. J. Essent. Oil Res. 2000, 12, 249-255. [CrossRef]

43. Christopher, F.; Stahl-Biskup, E.; Kaulfers, P.M. Death kinetics of Staphylococcus aureus exposed to commercial tea tree oils. J. Essent. Oil. Res. 2001, 13, 98-102. [CrossRef]

44. Hammer, K.A.; Carson, C.F.; Riley, T.V. In vitro susceptibilities of lactobacilli and organisms associated with bacterial vaginosis to Melaleuca alternifolia (tea tree) oil. Antimicrob. Agents Chemother. 1999, 43, 196. [CrossRef] [PubMed]

45. Shapiro, S.; Meier, A.; Guggenheim, B. The antimicrobial activity of essential oils and essential oil components towards oral bacteria. Oral Microbiol. Immunol. 1994, 9, 202-208. [CrossRef]

46. Banes-Marshall, L.; Cawley, P.; Phillips, C.A. In vitro activity of Melaleuca alternifolia (tea tree) oil against bacterial and Candida spp. isolates from clinical specimens. Br. J. Biomed. Sci. 2001, 58, 139-145.

47. Southwell, I.A.; Hayes, A.J.; Markham, J.; Leach, D.N. The search for optimally bioactive Australian tea tree oil. Int. Symp. Med. Aromat. Plants 1993, 344, 256-265. [CrossRef]

48. Carson, C.F.; Mee, B.J.; Riley, T.V. Mechanism of action of Melaleuca alternifolia (tea tree) oil on Staphylococcus aureus determined by time-kill, lysis, leakage, and salt tolerance assays and electron microscopy. Antimicrob. Agents Chemother. 2002, 48, 1914-1920. [CrossRef] [PubMed]

49. Shin, S. Anti-Aspergillus activities of plant essential oils and their combination effects with ketoconazole or amphotericin B. Arch. Pharmacol. Res. 2003, 26, 389-393. [CrossRef] [PubMed]

50. Siddique, S.; Parveen, Z.; Butt, A.; Chaudhary, M.N.; Akram, M. The essential oil of Melaleuca armillaris (Sol. ex Gaertn.) Sm. leaves from Pakistan: A potential source of eugenol methyl ether. Inds. Crops Prod. 2017, 109, 912-917. [CrossRef]

51. Homeyer, D.C.; Sanchez, C.J.; Mende, K.; Beckius, M.L.; Murray, C.K.; Wenke, J.C.; Akers, K.S. In vitro activity of Melaleuca alternifolia (tea tree) oil on filamentous fungi and toxicity to human cells. Med. Mycol. 2015, 53, 285-294. [CrossRef] [PubMed] 